\title{
Chemical Composition, Anti-Nutritional Factors and Pasting Properties of Cassava-African Yam Bean Flour Blends for Noodle Preparation
}

\author{
Ghaniyah O. Ajibola ${ }^{a^{*}}$ And Abiodun A. Olapade ${ }^{\mathrm{a}}$ \\ ${ }^{a}$ Department of Food Technology, Faculty of Technology, University of Ibadan, Ibadan, Nigeria. \\ ${ }^{*}$ Corresponding author \\ aiibolaghanivah@yahoo.com \\ TEL.: +234-8056348979
}

Received: 14 November 2017; Published online: 24 February 2021

\begin{abstract}
Noodle consumption has been increasing in Nigeria as a result of rapid urbanization, increase in population growth, and desire for convenience food. Noodles are produced from wheat flour which is not grown in Nigeria. In order to reduce wheat imports and improve utilization of local crops, various options have been developed to replace wheat flour partially or wholly in noodle production. This study was aimed at optimizing the level of major ingredients to obtain the best flour blend for noodle preparation with optimum nutritional quality. Pro-vitamin A cassava roots (Manihot esculenta Crantz) and African yam bean seeds (AYB) (Sphenostylis stenocarpa) were processed into flours. The ranges of these flours, based on preliminary findings, were computed into a central composite design of Response Surface Methodology (RSM) to obtain 13 flour blends with five central points. The chemical compositions, anti-nutritional factors, and pasting properties of these flour blends were analyzed and measured. By maximizing total $\beta$-carotene, protein content, and minimizing fat content, the predicted model indicated the optimum blend of $70.52 \%$ cassava flour to $29.48 \%$ AYB flour. The best flour blend sample of $69.23 \%$ cassava flour to $30.77 \%$ AYB flour gave the actual value of total $\beta$-carotene 6.76 $\mu \mathrm{g} / \mathrm{g}$, with proximate analysis composition of protein $6.17 \%$, fat $0.82 \%$, moisture $8.95 \%$, ash $1.77 \%$, crude fiber $5.09 \%$, and carbohydrate $82.30 \%$. The anti-nutritional factors of the best blend were 8.21 $\mathrm{mg} \mathrm{HCN}_{e q v} / \mathrm{kg}, 1.69 \mathrm{mg}$ phytate/g and $0.37 \mathrm{mg}$ tannin/g.
\end{abstract}

Keywords: Flour blends; Noodles; Nutritional quality; Pro-vitamin A cassava; Response Surface Methodology

\section{Introduction}

Many developing countries spend an exorbitant amount of their foreign exchange on importation of wheat (Ohimain, 2014). This is due to the high rate of wheat consumption in those countries. According to Oyeku et al. (2008), it would be of great economic importance if wheat importation is minimized drastically by replacing it with other locally available raw materials such as cassava, rice, cowpea, maize, potato. Seibel (2006) opined that no other crop can accomplish the baking properties of wheat. Hence, composite flour has become the emphasis of various studies. There has arisen the need to use affordable indigenous crops that still provide optimum nutritive value and good processing attributes to substitute for wheat flour in the food industry.

Local raw material replacement for wheat flour is increasingly essential due to the rising market 
for confectioneries (Noor Aziah \& Komathi, 2009) and convenience foods in emerging countries. Thus, many developing countries have encouraged the commencement of programmes to assess the feasibility of alternative and locally accessible flours as a substitute for wheat flour (Abdelghafor, Mustafa, Ibrahim \& Krishnan, 2011). Therefore, utilization of composite flour is considered beneficial in emerging nations as it decreases the imported wheat flour and boosts the use of indigenous crops as flour (Hugo, Rooney \& Taylor, 2000; Mamat et al., 2014). This will generate income for farmers, motivate cultivation of indigenous crops, create employment opportunities and thereby improve local economies.

Babatunde (2012) opined that large components of helpless populations, women of child-bearing age and children in regions where cassava consumption is high, were vulnerable to vitamin A deficiency. According to UNICEF (2004) and World Bank (2009), Nigeria loses over US\$1.5 billion per annum in Gross Domestic Product (GDP) to vitamin and mineral deficiencies as many staple foods are very low in essential micronutrients. Therefore, adopting strategies to reduce these problems is highly essential. In view of this, biofortification of staple crops with pro-vitamin A carotenoid is an evolving approach to address the low vitamin A status of the people (Tanumihardjo, Bouis, Hotz, Meenakshi \& McClafferty, 2008). This has promoted the biofortification of cassava.

Yellow-fleshed cassava (Manihot esculenta Crantz) cultivar 070593 are being propagated in Nigeria to aid in fighting dietary vitamin A deficiency due to their high content in $\beta$-carotene (a precursor of vitamin A) (Omodamiro et al., 2012). Since cassava is a major staple food crop in Nigeria, consumption of this pro-vitamin A cassava would help in combating vitamin A deficiency, a serious public health problem in many parts of the world including Nigeria (Omodamiro et al., 2011; Thakkar, Huo, Maziya-Dixon \& Failla, 2009; Vimala, Thushara, Nambisan \& Sreekumar, 2011). One of the restrictive factors to the utilization of cassava flour (CF) in food production is its low protein content. Therefore, fortification with protein-rich flour is required to improve the nutritional value of $\mathrm{CF}$ formulated food.

The anti-nutrients like trypsin inhibitors, phytic acid, saponins, heamagglutinins and tannins are some of the undesirable components in legumes that could hinder utilization of important minerals such as calcium, magnesium, iron and zinc. They interfere with the absorption and utilization of minerals and thereby contribute to mineral deficiency (Qayyum, Butt, Anjum \& Nawaz, 2012; Vasagam \& Rajkumar, 2011). They are generally toxic and may negatively affect the nutrient value of legume seeds by impairing protein digestibility and mineral availability. However, they are heat labile and hence may be inactivated by processing methods involving heat (Ndidi et al., 2014).

According to Bouchenak and Lamri-Senhadji (2013), legumes represent essential parts of the human diet in several areas of the world, particularly in the developing countries, where they compensate for the lack of protein from diets rich in cereals, roots and tubers. Nwokeke, Adedokun and Osuji (2013) opined that African yam bean seed (AYB) (Sphenostylis stenocarpa) is one of the best sources for protein supplementation of starchy foods. It has been chosen to fortify starch-based food due to its nutritional potential to enrich food. The use of AYB will also promote the utilization of this lesser-known and under-utilized legume in a number of food preparations in developing countries. The general objective of this study is to evaluate the nutritional quality of pro-vitamin A cassava-AYB flour blends for noodle preparation. The specific objectives include assessment of chemical, anti-nutritional factors, and pasting properties of pro-vitamin A cassava and AYB flour blends. 


\section{Materials and Methods}

\section{$2.1 \quad$ Sources of materials}

Pro-vitamin A (yellow-fleshed) cassava (Manihot esculenta Crantz) of cultivar 070593 and African yam bean (AYB) (Sphenostylis stenocarpa) of accession (TSs 94) were obtained from the Cassava Processing Unit and Genetic Resources Centre (GRC) of the International Institute of Tropical Agriculture (IITA) Ibadan, Nigeria.

\section{$2.2 \quad$ Preparation of flours}

Pro-vitamin A cassava roots were harvested 1012 months after planting, sorted and processed into flours based on the method described by Aniedu and Omodamiro (2012). Cassava roots were peeled manually, washed in clean water, grated and dewatered with the use of 50 ton pressing equipment. The wet cake obtained was pulverised to decrease the size and increase the surface area. The pulverised wet cake was dried employing a Niji Lukas Flash dryer located at IITA, Ibadan at a temperature of $130{ }^{\circ} \mathrm{C}$ for 20 $\mathrm{s}$ residence time. The dried cassava flour was milled, cooled to room temperature and sieved with $250 \mu \mathrm{m}$ sieve prior to packaging. AYB seeds were processed into flour according to the method described by Nwosu, Ahaotu, Ayozie, Udeozor and Ahaotu (2011) with a slight modification. The seeds were cleaned, sorted and soaked in water with seed to water ratio of $1: 3$ for $24 \mathrm{~h}$. The modification involved boiling of soaked seeds at $100{ }^{\circ} \mathrm{C}$ for $10 \mathrm{~min}$. These were drained, cooled and manually dehulled. The dehulled seeds were washed to separate the seed coats and oven dried at $60{ }^{\circ} \mathrm{C}$ for $6 \mathrm{~h}$. The dried seeds were milled, cooled, and sieved through a $250 \mu \mathrm{m}$ sieve to obtain AYB flour and packaged in a low-density polyethylene bag until analysis.

\subsection{Experimental design}

This study adopted Response Surface Methodology (RSM) according to the central composite rotatable design (CCD) for the establishment of test flour blends using Design Expert version 6.0.6 (Stat-Ease Inc., Minneapolis). Two major ingredient factors, pro-vitamin A cassava flour and AYB flour, ranged from $60-90 \%$ and $10-40 \%$, respectively. These ranges were chosen based on preliminary findings on noodle preparation in our laboratory. This generated 13 combinations with five central points as depicted in Table 1 . The central point was repeated five times to analyse the reproducibility of the method.

\section{Flour blends preparation}

Pro-vitamin A cassava and AYB flours were weighed and thoroughly mixed at predetermined ratios using a Bajaj grinder mixer (model GX 10 DLX, Bajaj Electrical Limited Mumbai, India) for 1 min to obtain a homogenous flour blend.

\subsection{Chemical analyses of flours and flour blends}

\section{$\beta$-carotene determination}

The method of Carvalho et al. (2012) was followed with slight modification to determine $\beta$ carotene and its isomers. Ten grams of each sample were weighed and crushed with mortar to aid $\beta$-carotene extraction. Distilled water was added to soak the sample for $5 \mathrm{~min}$, then $30 \mathrm{~mL}$ of acetone $\left(\mathrm{C}_{3} \mathrm{H}_{6} \mathrm{O}\right.$, Merck, KGaA, Germany) was added. This was left for $20 \mathrm{~min}$ and $3 \mathrm{~g}$ of celite $\left(\mathrm{SiO}_{2}, \mathrm{FOSS}\right.$, North America) was added to aid the extraction. A pestle was used to crush the sample 3 times for about 5 min each time and acetone was added to the sample at each crushing time until it was completely extracted. This was filtered in a Buchner funnel containing filter paper connected to a pump to aid the filtration. The extract was transferred to a $500 \mathrm{~mL}$ separation funnel containing $40 \mathrm{~mL}$ of petroleum ether $\left(\mathrm{C}_{6} \mathrm{H}_{14}\right.$, Thermo Fisher Scientific, Waltham, US). The acetone was used to rinse the container to ensure all the extracts were removed. This acetone was carefully removed by washing via slow addition of distilled water into the extract. This procedure was repeated four times until no residual solvent remained. The lower phase, being water was discarded and the upper phase was carefully transferred via a small funnel containing cotton wool and anhydrous sodium sulphate

IJFS | February 2021 | Volume 10| pages SI1-SI13 
Table 1: Experimental design for flour blend optimization of pro-vitamin A cassava flour (CF) and African yam bean flour (AYBF), and actual experimental values of the blends

\begin{tabular}{|c|c|c|c|c|c|c|c|}
\hline \multirow[b]{2}{*}{ Trials } & \multicolumn{2}{|c|}{ Coded values } & \multicolumn{5}{|c|}{ Actual experimental values } \\
\hline & ${ }^{*} \mathrm{CF}$ & *AYBF & $\begin{array}{l}\mathrm{CF} \\
(\%)\end{array}$ & $\begin{array}{c}\mathrm{AYBF} \\
(\%)\end{array}$ & $\begin{array}{c}\beta \text {-carotene } \\
(\mu \mathrm{g} / \mathrm{g})\end{array}$ & $\begin{array}{c}\text { Protein } \\
(\%)\end{array}$ & $\begin{array}{l}\text { Fat } \\
(\%)\end{array}$ \\
\hline 1 & 0 & -1.414 & 94.49 & 5.51 & 7.61 & 2.31 & 0.73 \\
\hline 2 & 1 & -1 & 90.00 & 10.00 & 6.68 & 2.88 & 0.75 \\
\hline 3 & 1.414 & 0 & 80.06 & 19.94 & 6.37 & 5.08 & 0.86 \\
\hline 4 & -1 & -1 & 80.00 & 20.00 & 6.82 & 5.03 & 1.00 \\
\hline 5 & 0 & 0 & 72.22 & 27.78 & 6.57 & 6.54 & 0.58 \\
\hline 6 & 0 & 0 & 72.22 & 27.78 & 6.59 & 6.48 & 0.58 \\
\hline 7 & 0 & 0 & 72.22 & 27.78 & 6.58 & 6.02 & 0.58 \\
\hline 8 & 0 & 0 & 72.22 & 27.78 & 6.58 & 6.35 & 0.58 \\
\hline 9 & 0 & 0 & 72.22 & 27.78 & 6.61 & 5.08 & 0.56 \\
\hline 10 & 1 & 1 & 69.23 & 30.77 & 6.76 & 6.17 & 0.82 \\
\hline 11 & 0 & 1.414 & 58.45 & 41.55 & 3.50 & 9.17 & 1.04 \\
\hline 12 & -1.414 & 0 & 54.25 & 45.75 & 5.90 & 9.77 & 1.40 \\
\hline 13 & -1 & 1 & 50.00 & 50.00 & 4.69 & 10.52 & 1.05 \\
\hline
\end{tabular}

$\left(\mathrm{Na}_{2} \mathrm{SO}_{4}, \mathrm{BDH}\right.$ laboratory supplies, England) to remove residual water. This was made up to 25 $\mathrm{mL}$ with petroleum ether and allowed to settle. Fifteen millimetres of the extract were pipetted into a concentrator tube and concentrated at $40^{\circ} \mathrm{C}$ for 25 min. in a TurboVap ${ }^{\circledR} \mathrm{LV}$ concentration workstation (Caliper Life Sciences, U.S.A.). The concentrate was diluted with $1 \mathrm{~mL}$ of dichloroethane $\left(\mathrm{CH}_{2} \mathrm{Cl}_{2}, \mathrm{BDH}\right.$, Bristol, UK) and 1 $\mathrm{mL}$ of methanol $\left(\mathrm{CH}_{3} \mathrm{OH}\right.$, Sigma Aldrich, Germany). This was mixed in a vortex mixer and transferred to a 2-mL amber flask for subsequent analysis using High Performance Liquid Chromatography (HPLC) (Agilent 1200 series, Perkin Elmer, USA, $\beta$-carotene standard: CAS: 723540-7, Sigma Aldrich, Germany, column: YMC carotenoids column 250x4.6x $5 \mu \mathrm{m}$, detector: PDA Waters 2695, Solvents: dichloromethane: cat no 67-56-1 and methyl tert-butyl ether, cat no 1634-04-4, Fisher Loughborough, UK.). Empower 3 chromatography data software was used to scan each sample and values obtained were input into equation (1) to determine the content of $\beta$-carotene and its isomers $(\mu g / g)$.

$$
C=\frac{A_{x} \times C_{s} \times V}{A_{s} \times P}
$$

where $\mathrm{A}_{x}=$ carotenoid peak area, $\mathrm{C}_{s}(\mu g / m l)=$ standard concentration, $\mathrm{A}_{s}=$ standard area, $\mathrm{V}=$ total extract volume $(\mathrm{ml})$ and $\mathrm{P}=$ sample weight (g).

\section{Proximate composition of flour blends}

Moisture and ash contents of the flour blends were determined as described in AOAC (2005). The crude protein was determined by the Kjeldahl method using a FOSS Kjeltec 2300 model protein analyser as described by Alamu, Maziya-Dixon, Popoola, Gondwe and Chikoye (2016) with slight modifications. The modifications involved the addition of $12 \mathrm{~mL}$ of concentrated $\mathrm{H}_{2} \mathrm{SO}_{4}$ instead of $4 \mathrm{~mL} .0 .15 \mathrm{~g}$ of sample was weighed into a digestion tube, a tablet of Kjeldahl catalyst and $12 \mathrm{~mL}$ of concentrated $\mathrm{H}_{2} \mathrm{SO}_{4}$ were added. The crude fat contents of the flour blends were determined as described in AACC (2005) using an automated method (FOSS, Soxtec system HT2). The crude fibre contents of the flour blends were determined as described in AOAC (1990) using FOSS Fibertec 2010 equipment.

The total carbohydrate contents were calculated by difference as reported by Koua et al. (2012).

IJFS | February 2021 | Volume 10 | pages SI1-SI13 


\section{Anti-nutritional composition of flour blends}

The method of alkaline picrate as described by Onwuka (2005) was adopted in determining hydrogen cyanide contents, while the phytate contents of flour blends were determined based on the method described by Maga (1982). Tannin content was determined based on the method described by Fagbemi, Oshodi and Ipinmoroti (2005) with slight amendments.

\subsection{Determination of pasting characteristics of flour blends}

Pasting properties of the flour blends were determined as described in AACC (2005) using a Rapid Visco Analyser Super 4 (Model RVA-4C, Newport Scientific, Warriewood, Australia). The pasting properties: peak viscosity, trough, breakdown viscosity, setback value, final viscosity in centipoise $(\mathrm{cP})$, pasting temperature $\left({ }^{\circ} \mathrm{C}\right)$ and peak time $(\mathrm{min})$ were obtained. These viscosities were converted to RVU (Rapid Visco Unit) with the conversion factor $12 \mathrm{cP}=1 \mathrm{RVU}$.

\subsection{Optimization of flour blends}

The optimisation procedure as described by Delgado, Paim, Pereira, Casal and Ramalhosa (2018) was followed. The Design expert software version 6.0.6 (Stat-Ease Inc., Minneapolis) was used in this study. The ranges of pro-vitamin A cassava flour (CF) and AYB flours (AYBF) as obtained from preliminary study were inserted into the design expert to generate the number of flour blends. These flour blends were optimized based on the chosen quality parameters, i.e., maximizing total $\beta$-carotene and protein contents to improve the nutritional value, while minimizing fat content to avoid rancidity of flours. The mean of duplicate analysis values (see below) of total $\beta$ carotene, protein, and fat content were employed to find an optimum flour blend value by fitting polynomial models. The coefficients of polynomial models, coefficient of determination $\left(\mathrm{R}^{2}\right)$, adjusted $R^{2}$ and adequate precision values of the chemical properties of the blends were used to evaluate the model fitness as indicated in Table 2 .

\subsection{Statistical analysis}

Data from analysis of flour blends were subjected to one-way analysis of variance (ANOVA) using Statistical Package for Social Sciences (SPSS) (version 20, 2013). Means were equated and separated using Duncan's New Multiple Range Test (DMRT) and LSD at $(\mathrm{p} \leq 0.05)$. Design expert was also used for data analysis.

\section{Results and Discussion}

\subsection{Chemical composition of flour blends}

The total $\beta$-carotene contents of flour blends ranged from 3.50 to $7.61 \mu \mathrm{g} / \mathrm{g}$ flour. The flour blend 94.49CF:5.51AYBF had the highest $\beta$ carotene, while sample $58.45 \mathrm{CF}: 41.55 \mathrm{AYBF}$ had the least. There were significant $(\mathrm{p} \leq 0.05)$ differences among the flour blends based on their total $\beta$-carotene contents as shown in Table 3 . It was observed that as AYB flour increased in the blend, the $\beta$-carotene content decreased.

The proximate composition of flour blends is shown in Table 4. There were significant differences $(p \leq 0.05)$ in proximate composition of the flour blends due to different composition of the flours. The moisture contents of the flour blends ranged from 8.12 to $10.13 \%$ with the blend 54.25CF:45.75AYBF having the highest moisture content, while the blend 90CF:10AYB had the lowest. These values fell within the ranges obtained by Iwe, Onyeukwu, Agiriga and Yildiz (2016) with values of $8-14 \%$ and compared with $13 \%$ maximum recommended moisture content for edible cassava flour by the Standard Organization of Nigeria (SON) as reported by Sanni et al. (2005).

The fat contents of the flour blends ranged from 0.56 to $1.4 \%$. The blend $54.25 \mathrm{CF}: 45.75 \mathrm{AYBF}$ had the highest fat content, while the blend 72.22CF:27.78AYBF had the least. The reason for this low fat content might be that cereals and tubers accumulate energy in the form of starch 
SI6 $\mid$ Ajibola and Olapade

Table 2: Coefficient of polynomial models of RSM for pro-vitamin A cassava flour and African yam bean flour blends

\begin{tabular}{lcccccc}
\hline $\begin{array}{l}\text { Variables } \\
\text { Terms }\end{array}$ & $\begin{array}{c}\beta \text {-carotene } \\
\text { Coefficient }\end{array}$ & $\mathrm{P}$ & $\begin{array}{c}\text { Protein } \\
\text { Coefficient }\end{array}$ & $\mathrm{P}$ & $\begin{array}{c}\text { Fat } \\
\text { Coefficient }\end{array}$ & $\mathrm{P}$ \\
\hline Constant & 6.59 & 0.0005 & 6.38 & 0.0001 & 0.58 & 0.008 \\
$\mathrm{~A}_{1}$ & 0.54 & 0.0032 & -1.64 & 0.0001 & -0.17 & 0.0059 \\
$\mathrm{~B}_{2}$ & -0.76 & 0.0005 & 2.31 & 0.0001 & 0.05 & 0.3039 \\
$\mathrm{~A}_{1}^{2}$ & 0.18 & 0.2105 & 0.42 & 0.009 & 0.2 & 0.0038 \\
$\mathrm{~B}_{2}^{2}$ & -0.73 & 0.0009 & -0.43 & 0.008 & 0.13 & 0.0263 \\
$\mathrm{~A}_{1} \mathrm{~B}_{2}$ & 0.56 & 0.0155 & -0.55 & 0.0089 & 0.06 & 0.3953 \\
Lack of fit $_{\mathrm{R}^{2}}^{\mathrm{S}}$ & 0.0001 & $\mathrm{~ns}$ & 0.1199 & $\mathrm{~s}$ & 0.0001 \\
Adjusted $\mathrm{R}^{2}$ & 0.9360 & & 0.9904 & & 0.8525 & \\
Adequate precision & 0.8902 & & 0.9836 & & 0.7491 & \\
Model & 15.463 & & 41.266 & & 7.611 & \\
\hline $\mathrm{A}_{1}$ & Quadratic & & Quadratic & & Quadratic & \\
\hline
\end{tabular}

$\mathrm{A}_{1}$ denotes Pro-vitamin A cassava flour, $\mathrm{B}_{2}$ denotes African yam bean flour, $\mathrm{R}^{2}$

denotes coefficient of determination, s denotes significant, ns signifies non-significant.

rather than lipids. Moreover, these low-fat contents are beneficial as they ensure longer shelf life of the flours (Beebe, Viviana Gonzalez \& Rengifo, 2000).

The protein content of the flour blends varied from 2.31 to $10.52 \%$. The blend 50CF:50AYBF had the highest protein content, while the blend 94.49CF:5.51AYBF had the lowest. A significant increase in protein content was noted among the blends as the quantity of AYB flour increased. This increase was expected because AYB flour is rich in protein and was in agreement with results obtained from Idowu (2015) for a snack made from yellow maize and AYB flour blends. Production of high-quality noodles utilises flour of 7 to $9.5 \%$ protein content (Choy, 2011).

The ash contents of the flour blends ranged from 1.66 to $2.06 \%$ with sample coded 50CF:50AYBF having the highest while the blend 80CF:20AYBF had the lowest. These values fell within the range reported by Omeire, Kabuo, Nwosu, Peter-Ikechukwu and Nwosu (2015) for wheat cassava enriched noodles, values of $1.39-2.84 \%$. The crude fibre contents of the flour blends ranged from 3.19 to $5.09 \%$. Sample coded 69.23CF:30.77AYBF had the highest crude fibre. These values were lower than those obtained from Iwe et al. (2016), 0.95-6.27\% for composite flours made from FARO 44 rice, AYB and brown cowpea seeds. The carbohydrate content of the flour blends ranged from $76.60-86.86 \%$. The blend 94.49CF:5.51AYBF had the highest carbohydrate, while sample coded 50CF:50AYBF had the lowest. It was observed that as the quantity of AYB flour increased in the flour blends, the carbohydrate content decreased (Table 4).

\subsection{Anti-nutritional compositions of flour blends}

Table 5 shows the anti-nutritional composition of the flour blends. The hydrogen cyanide (HCN) composition ranged from 6.22 to $10.32 \mathrm{mg} \mathrm{HCN}_{\text {eqv }} / \mathrm{kg}$ with sample coded 94.49CF:5.51AYBF having the highest, while 58.45CF:41.55AYBF had the least. It was observed that hydrogen cyanide content of the blend decreased as the quantity of AYB flour increased in the blend. The phytate contents of the flour blends ranged from 1.08 to 2.44 $\mathrm{mg} / \mathrm{g}$ with sample coded 54.25CF:45.75AYBF and $94.49 \mathrm{CF}: 5.51 \mathrm{AYBF}$ having the highest and least, respectively. The tannin contents of the flour blends ranged from 0.11 to $0.63 \mathrm{mg} / \mathrm{g}$ with sample coded 50CF:50AYBF having the highest, while sample 94.49CF:5.51AYBF had the least. There were significant $(\mathrm{p} \leq 0.05)$ dif- 
Nutritional Quality of Cassava-African Yam Bean Flour Blends |SI7

Table 3: Total $\beta$-carotene of pro-vitamin A cassava flour (CF) and African yam bean flour blends

\begin{tabular}{lccccccc}
\hline $\begin{array}{l}\text { Sample code } \\
\text { CF: AYBF }(\%)\end{array}$ & $\begin{array}{c}\text { Coded value } \\
\mathrm{A}\end{array}$ & $\begin{array}{c}\text { Coded value } \\
\mathrm{B}\end{array}$ & $\begin{array}{c}\beta- \\
\text { cryptoxanthin } \\
(\mu \mathrm{g} / \mathrm{g})\end{array}$ & $\begin{array}{c}\text { 13-cis } \\
(\mu \mathrm{g} / \mathrm{g})\end{array}$ & $\begin{array}{c}\text { Trans } \\
(\mu \mathrm{g} / \mathrm{g})\end{array}$ & $\begin{array}{c}\text { 9-cis } \\
(\mu \mathrm{g} / \mathrm{g})\end{array}$ & $\begin{array}{c}\text { Total } \\
\beta \text {-Carotene } \\
(\mu \mathrm{g} / \mathrm{g})\end{array}$ \\
\hline 94.49CF:5.51AYBF & 0 & -1.414 & $0.86^{d}$ & $1.71^{d}$ & $3.76^{e}$ & $2.13^{c}$ & $7.61^{d}$ \\
90CF:10AYBF & 1 & -1 & $0.76^{e}$ & $1.51^{e}$ & $3.28^{f}$ & $1.89^{d}$ & $6.67^{g h i}$ \\
80.06CF:19.94AYBF & 1.414 & 0 & $0.97^{c}$ & $1.46^{e f}$ & $2.97^{g}$ & $1.93^{d}$ & $6.36^{j}$ \\
80CF:20AYBF & -1 & -1 & $0.74^{e f}$ & $1.54^{e}$ & $3.34^{f}$ & $1.93^{d}$ & $6.82^{f g}$ \\
72.22CF:27.78AYBF & 0 & 0 & $0.63^{g}$ & $1.39^{f}$ & $3.29^{f}$ & $1.89^{d}$ & $6.57^{h i}$ \\
72.22CF:27.78AYBF & 0 & 0 & $0.64^{g}$ & $1.39^{f}$ & $3.29^{f}$ & $1.91^{d}$ & $6.59^{h i}$ \\
72.22CF:27.78AYBF & 0 & 0 & $0.63^{g}$ & $1.39^{f}$ & $3.28^{f}$ & $1.91^{d}$ & $6.58^{h i}$ \\
72.22CF:27.78AYBF & 0 & 0 & $0.64^{g}$ & $1.39^{f}$ & $3.29^{f}$ & $1.90^{d}$ & $6.57^{h i}$ \\
72.22CF:27.78AYBF & 0 & 0 & $0.63^{g}$ & $1.39^{f}$ & $3.30^{f}$ & $1.91^{d}$ & $6.61^{h i}$ \\
69.23CF:30.77AYBF & 1 & 1 & $0.73^{f}$ & $1.50^{e}$ & $3.36^{f}$ & $1.91^{d}$ & $6.76^{f g h}$ \\
58.45CF:41.55AYBF & 0 & 1.414 & $0.41^{j}$ & $0.78^{i}$ & $1.73^{j}$ & $0.99^{h}$ & $3.50^{m}$ \\
54.25CF:45.75AYBF & -1.414 & 0 & $0.59^{h}$ & $1.25^{g}$ & $2.99^{g}$ & $1.53^{f}$ & $5.90^{k}$ \\
50CF:50AYBF & -1 & 1 & $0.49^{i}$ & $0.99^{h}$ & $2.36^{i}$ & $1.32^{g}$ & $4.69^{l}$ \\
\hline
\end{tabular}

$\mathrm{CF}=$ Pro-vitamin A cassava flour, AYBF $=$ African yam bean flour.

Mean value from triplicate determinations. Mean values with different superscripts within a column are significantly $(\mathrm{P} \leq 0.05)$ different.

Table 4: Proximate composition of pro-vitamin A cassava flour (CF) and African yam bean flour (AYBF) and their flour blends

\begin{tabular}{|c|c|c|c|c|c|c|c|c|}
\hline $\begin{array}{l}\text { Sample } \\
\text { code } \\
\text { CF: AYBF }(\%)\end{array}$ & $\begin{array}{l}\text { Coded } \\
\text { value } \\
\text { A }\end{array}$ & $\begin{array}{l}\text { Coded } \\
\text { value } \\
\text { B }\end{array}$ & $\begin{array}{c}\text { Moisture } \\
(\%)\end{array}$ & $\begin{array}{l}\text { Fat } \\
(\%)\end{array}$ & $\begin{array}{l}\text { Protein } \\
(\%)\end{array}$ & $\begin{array}{l}\text { Ash } \\
(\%)\end{array}$ & $\begin{array}{l}\text { Crude } \\
\text { fibre } \\
(\%)\end{array}$ & $\begin{array}{c}\text { Carbohydrate } \\
(\%)\end{array}$ \\
\hline 94.49CF:5.51AYBF & 0 & -1.414 & $8.35 \pm 0.24^{f g}$ & $0.73 \pm 0.07^{e f}$ & $2.31 \pm 0.13^{j}$ & $1.75 \pm 0.02^{b c d}$ & $4.01 \pm 0.18^{\text {cde }}$ & $86.86 \pm 0.34^{a}$ \\
\hline $90 \mathrm{CF}: 10 \mathrm{~A}$ & 1 & -1 & $12+0$ & $75 \pm 0.04^{d e}$ & $2.88 \pm 0$ & $1.77 \pm 0.06^{b c}$ & $4.26 \pm 0.19^{b c}$ & $86.48 \pm 0.19^{b}$ \\
\hline 80.06CF:19.94AYBF & 1.414 & 0 & $8.61 \pm 0.16^{f g}$ & $0.86 \pm 0.04^{d}$ & $5.08 \pm 0.10^{h}$ & $1.80 \pm 0.01^{b}$ & $3.98 \pm 0.06^{\text {cde }}$ & $83.65 \pm 0.15^{c}$ \\
\hline $80 \mathrm{CF}: 20 \mathrm{AYBF}$ & -1 & -1 & $9.55 \pm 0.09^{c d}$ & $1.00 \pm 0.05^{c}$ & $5.03 \pm 0.16^{h}$ & $1.66 \pm 0.01^{d}$ & $3.76 \pm 0.27^{\text {def }}$ & $82.76 \pm 0.15^{d}$ \\
\hline $72.22 \mathrm{CF}: 27.78 \mathrm{AYBF}$ & 0 & 0 & $9.77 \pm 0.18^{b c}$ & $0.59 \pm 0.04^{h}$ & $6.54 \pm 0.10 \mathrm{e}$ & $1.70 \pm 0.01^{b c d}$ & $4.53 \pm 0.33^{b}$ & $81.39 \pm 0.21^{g}$ \\
\hline 72.2 & 0 & 0 & $9.53 \pm 0.27^{\text {cd }}$ & $0.57 \pm 0.03^{h}$ & $6.48 \pm 0$ & $1.68 \pm 0.06^{c d}$ & $4.20 \pm 0.34^{b c d}$ & $81.75 \pm 0.41^{f g}$ \\
\hline 72.2 & 0 & 0 & $9.62 \pm 0.09^{b c}$ & $0.58 \pm 0.01^{h}$ & $6.02 \pm 0$ & $1.70 \pm 0.02^{b c d}$ & $3.61 \pm 0.50^{e f}$ & $82.09 \pm 0.18^{e f}$ \\
\hline 72.22CF:27.78AYBF & 0 & 0 & $9.79 \pm 0.07^{b c}$ & $0.61 \pm 0.05^{g h}$ & $6.35 \pm 0.16^{\text {ef }}$ & $1.72 \pm 0.01^{b c d}$ & $4.35 \pm 0.30^{b c}$ & $81.53 \pm 0.13^{g}$ \\
\hline $72.22 \mathrm{CF}: 27.78 \mathrm{AYBF}$ & 0 & 0 & $9.17 \pm 0.02^{d e}$ & $0.56 \pm 0.03^{h}$ & $6.48 \pm 0.10^{e}$ & $1.78 \pm 0.01^{b}$ & $3.19 \pm 0.14^{g}$ & $82.01 \pm 0.08^{e f}$ \\
\hline $69.23 \mathrm{CF}: 30.77 \mathrm{AYBF}$ & 1 & 1 & $8.95 \pm 0.04^{e f}$ & $0.82 \pm 0.06^{d}$ & $6.17 \pm 0.10^{f g}$ & $1.77 \pm 0.01^{b c}$ & $5.09 \pm 0.06^{a}$ & $82.30 \pm 0.16^{e}$ \\
\hline $58.45 \mathrm{CF}: 41.55 \mathrm{AYBF}$ & 0 & 1.414 & $10.13 \pm 0.08^{b}$ & $1.04 \pm 0.03^{c}$ & $9.17 \pm 0.13^{d}$ & $1.98 \pm 0.03^{a}$ & $4.17 \pm 0.13^{b c d}$ & $77.86 \pm 0.13^{i}$ \\
\hline $54.25 \mathrm{CF}: 45.75 \mathrm{AYBF}$ & -1.414 & 0 & $8.87 \pm 0.41^{e f}$ & $1.40 \pm 0.06^{b}$ & $9.77 \pm 0.10^{c}$ & $1.76 \pm 0.02^{b c}$ & $4.32 \pm 0.10^{b c}$ & $78.20 \pm 0.47^{h}$ \\
\hline 50CF:50AYBF & -1 & 1 & $9.77 \pm 0.18^{b c}$ & $1.05 \pm 0.04^{c}$ & $10.52 \pm 0.10^{b}$ & $2.06 \pm 0.04^{a}$ & $3.47 \pm 0.15^{f g}$ & $76.60 \pm 0.17^{j}$ \\
\hline 100:0 & & & $9.87 \pm 0.05$ & $0.54 \pm 0.0$ & $1.89 \pm 0.03^{k}$ & $1.29 \pm 0.05^{e}$ & $0.80 \pm 0.04^{i}$ & $86.98 \pm 0.16^{a}$ \\
\hline $0: 100$ & & & $11.72 \pm 0.63^{a}$ & $1.99 \pm 0.02^{a}$ & $19.6 \pm 0.15^{a}$ & $2.07 \pm 0.02^{a}$ & $2.90 \pm 0.18^{h}$ & $64.62 \pm 0.27^{k}$ \\
\hline
\end{tabular}

$\mathrm{CF}=$ Pro-vitamin A cassava flour, AYBF $=$ African yam bean flour. Mean triplicate determinations \pm standard deviation.

Mean values with different superscripts within a column are significantly $(\mathrm{P} \leq 0.05)$ different.

IJFS $\mid$ February 2021 | Volume 10| pages SI1-SI13 
SI8 $\mid$ Ajibola and Olapade

Table 5: Anti-nutritional compositions of pro-vitamin A cassava flour $(\mathrm{CF})$ and African yam bean flour $(\mathrm{AYBF})$ and their flour blends

\begin{tabular}{lccccc}
\hline $\begin{array}{l}\text { Sample code } \\
\text { CF: AYBF }(\%)\end{array}$ & $\begin{array}{c}\text { Coded value } \\
\text { A }\end{array}$ & $\begin{array}{c}\text { Coded value } \\
\text { B }\end{array}$ & $\begin{array}{c}\text { HCN } \\
(\mathrm{mg} / \mathrm{kg})\end{array}$ & $\begin{array}{c}\text { Phytate } \\
(\mathrm{mg} / \mathrm{g})\end{array}$ & $\begin{array}{c}\text { Tannin } \\
(\mathrm{mg} / \mathrm{g})\end{array}$ \\
\hline 94.49CF:5.51AYBF & 0 & -1.414 & $10.32 \pm 0.14^{a}$ & $1.08 \pm 0.10^{i}$ & $0.11 \pm 0.01^{h}$ \\
90CF:10AYBF & 1 & -1 & $10.18 \pm 0.35^{a}$ & $1.37 \pm 0.07^{g h}$ & $0.22 \pm 0.01^{g}$ \\
80.06CF:19.94AYBF & 1.414 & 0 & $9.41 \pm 0.22^{b}$ & $1.42 \pm 0.12^{g}$ & $0.24 \pm 0.01^{f g}$ \\
80CF:20AYBF & -1 & -1 & $9.39 \pm 0.15^{b}$ & $1.55 \pm 0.17^{f g}$ & $0.26 \pm 0.01^{f}$ \\
72.22CF:27.78AYBF & 0 & 0 & $8.81 \pm 0.35^{c}$ & $1.95 \pm 0.10^{e}$ & $0.26 \pm 0.03^{f}$ \\
72.22CF:27.78AYBF & 0 & 0 & $9.45 \pm 0.47^{b}$ & $2.00 \pm 0.10^{\text {de }}$ & $0.24 \pm 0.01^{f g}$ \\
72.22CF:27.78AYBF & 0 & 0 & $8.88 \pm 0.38^{c}$ & $2.09 \pm 0.20^{c d e}$ & $0.22 \pm 0.01^{g}$ \\
72.22CF:27.78AYBF & 0 & 0 & $9.51 \pm 0.46^{b}$ & $2.07 \pm 0.14^{c d e}$ & $0.21 \pm 0.01^{g}$ \\
72.22CF:27.78AYBF & 0 & 0 & $8.69 \pm 0.40^{c}$ & $1.89 \pm 0.15^{e}$ & $0.25 \pm 0.02^{f}$ \\
69.23CF:30.77AYBF & 1 & 1 & $8.21 \pm 0.22^{d}$ & $1.69 \pm 0.10^{f}$ & $0.37 \pm 0.02^{d}$ \\
58.45CF:41.55AYBF & 0 & 1.414 & $6.22 \pm 0.27^{g h}$ & $2.24 \pm 0.07^{b c}$ & $0.34 \pm 0.01^{e}$ \\
54.25CF:45.75AYBF & -1.414 & 0 & $7.31 \pm 0.27^{e f}$ & $2.44 \pm 0.06^{b}$ & $0.45 \pm 0.03^{c}$ \\
50CF:50AYBF & -1 & 1 & $7.99 \pm 0.14^{e}$ & $2.20 \pm 0.10^{c d}$ & $0.63 \pm 0.02^{b}$ \\
100:0 & & & $6.76 \pm 0.28^{g}$ & $1.38 \pm 0.07^{g h}$ & $0.34 \pm 0.01^{e}$ \\
0:100 & & & $3.47 \pm 0.05^{i}$ & $2.55 \pm 0.11^{a}$ & $0.82 \pm 0.01^{a}$ \\
\hline CF Provis
\end{tabular}

$\mathrm{CF}=$ Pro-vitamin A cassava flour, $\mathrm{AYBF}=$ African yam bean flour, $\mathrm{HCN}=$ hydrogen cyanide. Mean triplicate determinations \pm standard deviation. Mean values with different superscripts within a column are significantly $(\mathrm{P} \leq 0.05)$ different.

ferences among the samples in terms of their phytate and tannin contents. The chosen blend sample $69.23 \mathrm{CF}: 30.77 \mathrm{AYBF}$ contained $8.21 \mathrm{mg} \mathrm{HCN}_{\text {eqv }} / \mathrm{kg}$ of hydrogen cyanide, 1.69 $\mathrm{mg}$ phytate/g and $0.37 \mathrm{mg}$ tannin/g. This hydrogen cyanide fell within a safe level of no more than $10 \mathrm{mg} \mathrm{HCN}_{\text {eqv }} / \mathrm{kg}$ of cassava flour as recommended by the Food and Agriculture Organisation of the United Nations and World Health Organisation (FAO/WHO, 2013). The hydrogen cyanide, phytate and tannin contents in the flour blends were lower than the allowable level of 50 $\mathrm{mg} \mathrm{HCN}_{\text {eqv }} / \mathrm{kg}$ dry mass, 250-500 mg/100 g dry mass, and $20 \mathrm{mg} / \mathrm{g}$ dry mass, respectively for AYB seed as reported by Ndidi et al. (2014).

\subsection{Pasting properties of flour blends}

There were significant differences in the pasting properties of flour blends, except for their pasting temperatures as depicted in Table 6 . The peak viscosities of the blends ranged from 214.66 to 514.5 RVU with sample coded 94.49CF:5.51AYBF having the highest, while sample coded 50CF:50AYBF having the lowest. The trough viscosity varied from $157.58 \mathrm{RVU}$ to 206.5 RVU for flour blends. This measures the ability of the paste to withstand breakdown during cooling (Danbaba et al., 2012). A significant decrease was noted in peak and breakdown viscosities as the level of AYB flour in the mixtures increased. This is as a result of protein in AYB flour forming an insoluble system that traps swollen starch granules thus, preventing disintegration of the noodle surface which would make it soft and sticky (Harvey \& Morgenstern, 2001). Such a decrease was similarly reported by Dhull and Sandhu (2018) for wheat-fenugreek composite flour noodles. The peak and trough viscosities in this study were higher than those stated by Adegunwa, Bakare and Akinola (2012) for enriched noodles with values of 104.33-165.08 RVU and 51.67-109 RVU accordingly. The chosen blend (69.23CF:30.77AYBF) had high peak and trough viscosities which is good for noodle mak- 
Nutritional Quality of Cassava-African Yam Bean Flour Blends |SI9

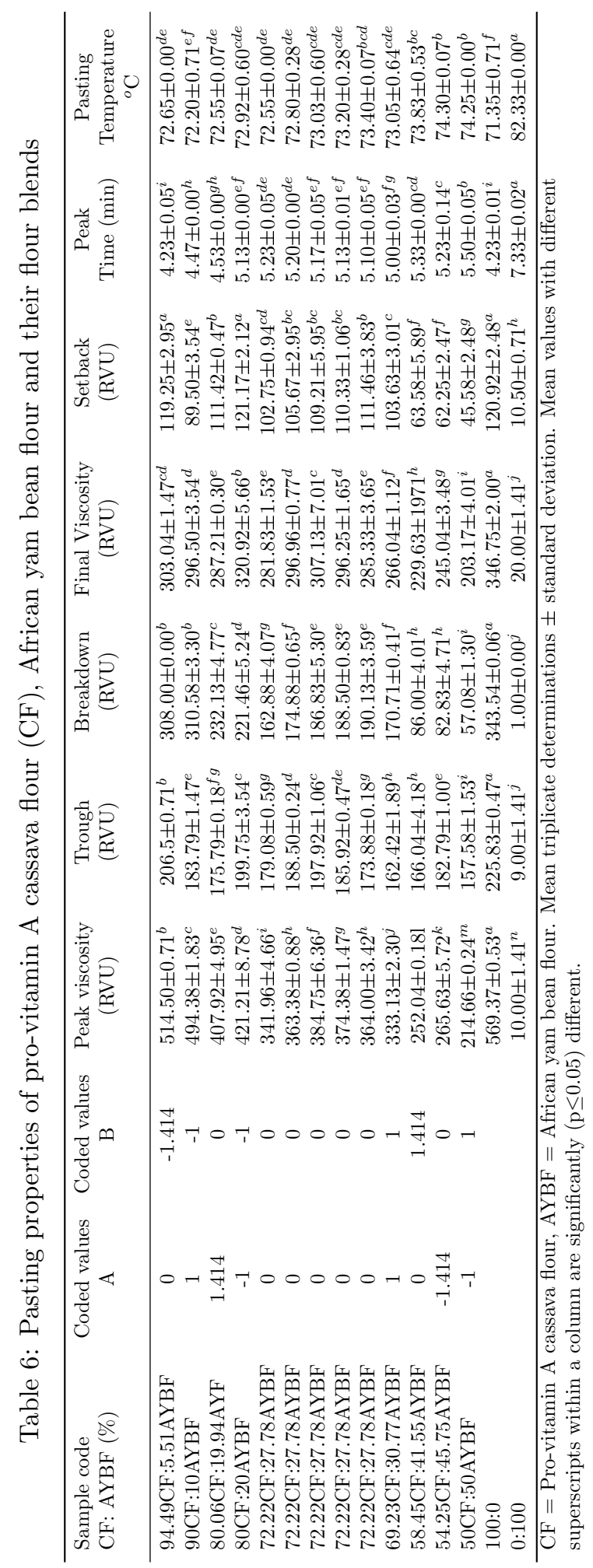

IJFS $\mid$ February 2021 $\mid$ Volume 10 $\mid$ pages SI1-SI13 
ing as high peak viscosity indicates that starch will not collapse as long as noodles are appropriately cooked. Likewise, Bhattacharya, Zee and Corke (1999) stated that high trough viscosity signifies low cooking loss and superior eating quality.

Breakdown viscosity of the flour blends ranged from 57.08 to 310.58 RVU with sample coded 90CF:10AYBF having the highest breakdown viscosity and sample 50CF:50AYBF the lowest. This is an index of the stability of the starch and measures the ease at which the gelatinized starch can be collapsed (Maninder, Sandhu \& Singh, 2007). Protein traps gelatinised starch thus reducing the breakdown viscosity and improving starch stability. Hence, low breakdown viscosity is desirable for good noodle quality.

The final viscosity of the flour blends ranged from 203.17 to 320.92 RVU. These values were higher than those stated by Adegunwa et al. (2012) with values of 126.42-217.08 RVU for noodles enriched with soy flour and carrot powder. The setback viscosity varied from 45.58 to 119.25 RVU with sample 94.49CF:5.51AYBF having the highest setback values. The chosen blend (69.23CF:30.77AYBF) had a moderate setback value of $103.63 \mathrm{RVU}$, good for producing quality noodles, and this value fell within the range stated by Adegunwa et al. (2012) with values of 73.25-118.42 RVU. It was noted that the sample with the lowest AYB flour inclusion had the highest setback value, thus undergoing faster syneresis. This faster syneresis causes rapid quality degradation which is not good for noodles. Peak time and pasting temperatures of flour blends ranged from 4.23 to $5.50 \mathrm{~min}$ and 72.20 to $74.30{ }^{\circ} \mathrm{C}$ accordingly. Adebowale, Sanni and Oladapo (2009) stated that a pasting temperature lower than the boiling temperature of water suggests that samples will form paste in hot water below its boiling point, thus potentially promoting cost saving.

\subsection{Predictive models and optimum flour blend conditions}

The effects of two independent variables $\mathrm{A}_{1}$ (provitamin $\mathrm{A}$ cassava flour) and $\mathrm{B}_{2}$ (AYB flour) on the responses: total $\beta$-carotene, protein and fat contents were modelled using the polynomial response surface models of the Design expert software. This provided equations that predict relationships between independent and response variables within a specified range as represented in equations (2) to (4). The equations (2) and (3) were for maximizing total $\beta$-carotene and protein contents, while equation (4) was for minimizing fat content of the flour blend.

$$
\begin{aligned}
& \text { Total } \beta-\text { carotene: } \\
& Y=6.59+0.54 A_{1}-0.76 B_{2}+0.18 A_{1}^{2} \\
& -0.73 B_{2}^{2}+0.56 A_{1} B_{2} \\
& \text { Protein: } \\
& Y=6.38-1.64 A_{1}+2.31 B_{2}+0.42 A_{1}^{2} \\
& -0.43 B_{2}^{2}-0.55 A_{1} B^{2} \\
& \text { Fat: } \\
& Y=0.58-0.17 A_{1}+0.049 B_{2}+0.2 A_{1}^{2} \\
& +0.13 B_{2}^{2}+0.057 A_{1} B_{2}
\end{aligned}
$$

Where $\mathrm{A}_{1}=$ Pro-vitamin $\mathrm{A}$ cassava flour and $\mathrm{B}_{2}$ $=$ African yam bean flour.

The estimation of how well the model fits the data can be assessed by the value of $\mathrm{R}^{2}$, adjusted $\mathrm{R}^{2}$ and adequate precision. The $\mathrm{R}^{2}$ ranges from 0 to 1 ; when it is nearer to 1 the regression equation estimation fits the sample data very well. The composite desirability has a range of zero to one. One signifies the ideal case, while zero denotes that one or more responses are not within their satisfactory boundaries. It was observed that $\mathrm{R}^{2}$ and adjusted $\mathrm{R}^{2}$ for the chosen models for $\beta$ carotene, protein and fat contents were greater than 0.80 and therefore indicated good fit models (Table 2). The models for total $\beta$-carotene, protein and fat contents were quadratic, and found to be significant for total $\beta$-carotene and fat with 'Prob $>$ F' less than 0.05 .

The predicted optimum blend from the RSM calculation was 70.52CF:29.48AYBF which yielded response values for total $\beta$-carotene, protein and fat content as $6.46 \mu \mathrm{g} / \mathrm{g}, 6.68 \%$ and $0.58 \%$, respectively. The desirability value of this optimum blend as obtained from the Design expert software was 0.725 . The actual experimental values of 69.23CF:30.77AYBF flour blend (Table 1 
Nutritional Quality of Cassava-African Yam Bean Flour Blends |SI11

trial 10) exhibited total $\beta$-carotene, protein and fat content values of $6.76 \mu \mathrm{g} / \mathrm{g}, 6.17 \%$ and $0.82 \%$, respectively, which was in agreement with predicted response values.

\section{Conclusion}

Response surface methodology was adopted in optimizing the pro-vitamin A cassava and African yam bean flour blends. The blends were formulated to maximize total $\beta$ carotene and protein content while minimizing fat content which resulted in recommended (predicted) values of the blend 70.52CF: 29.48AYBF. The blend coded 69.23CF:30.77AYBF was closest to the predicted value and thus, the best chosen blend for noodle preparation. This optimum blend would be suitable for developing cassava-African yam bean noodles. The protein content of pro-vitamin A cassava flour improved as the quantity of AYB flour increased in the blend. Our findings should promote the utilization of both local crops.

\section{Acknowledgements}

The authors appreciated the efforts of GRC and the Cassava Processing Unit of the International Institute of Tropical Agriculture for the provision of AYB seeds and cassava roots used for this research.

\section{References}

AACC. (2005). Approved methods of the American Association of Cereal Chemists, 11th Ed. St.Paul, MN.

Abdelghafor, R. F., Mustafa, A. I., Ibrahim, A. M. H. \& Krishnan, P. (2011). Quality of bread from composite flour of sorghum and hard white winter wheat. Advance Journal of Food Science and Technology, 3, 9-15.

Adebowale, A.-R., Sanni, S. A. \& Oladapo, F. O. (2009). Chemical, functional and sensory properties of instant yam - breadfruit flour. Nigerian Food Journal, 26. doi:10.4314/ nifoj.v26i1.47417
Adegunwa, M., Bakare, H. A. \& Akinola, O. F. (2012). Enrichment of noodles with soy flour and carrot powder. Nigerian Food Journal, 30, 74-81. doi:10 . 1016 / S0189 7241(15)30016-3

Alamu, E., Maziya-Dixon, B., Popoola, I., Gondwe, T. \& Chikoye, D. (2016). Nutritional evaluation and consumer preference of legume fortified maize-meal porridge. 4, 664-670. doi:10.12691/jfnr-4-10-6

Aniedu, C. \& Omodamiro, R. M. (2012). Use of newly bred beta-carotene cassava in production of value-added products: Implication for food security in nigeria. Global Journal of Science Frontier Research Agriculture and Veterinary Sciences, 12(10), $1-10$.

AOAC. (1990). Official Methods of Analysis, 15th Ed. Association of Official Analytical Chemists, Ed. Kenneth Helrich.

AOAC. (2005). Official Methods of Analysis, 18th Ed. Association of Official Analytical Chemists. Washington D.C., USA.

Babatunde, J. (2012). Journey to consumption of pro-vitamin A cassava varieties in $\mathrm{Ni}$ geria. Vanguard. Retrieved from www . vanguardngr.com

Beebe, S., Viviana Gonzalez, A. \& Rengifo, J. (2000). Research on trace minerals in the common bean. Food \& Nutrition Bulletin, 21. doi:10.1177/156482650002100408

Bhattacharya, M., Zee, S. Y. \& Corke, H. (1999). Physicochemical properties related to quality of rice noodles. Cereal Chemistry, 76 (6), 861-867. doi:10 . 1094 / CCHEM . 1999.76.6.861

Bouchenak, M. \& Lamri-Senhadji, M. (2013). Nutritional quality of legumes, and their role in cardiometabolic risk prevention: A review. Journal of Medicinal Food, 16(3), 185-198. doi:10.1089/jmf.2011.0238

Carvalho, L., Oliveira, A., Godoy, R., Pacheco, S., Nutti, M., Carvalho, J., ... G Fukuda, W. (2012). Retention of total carotenoid and beta-carotene in yellow sweet cassava (manihot esculenta crantz) after domestic cooking. Food \& Nutrition Research, 56. doi:10.3402/fnr.v56i0.15788

Choy, A. (2011). Enhancing the quality of instant noodles: The impact of low protein wheat

IJFS $\mid$ February 2021 $\mid$ Volume 10 $\mid$ pages SI1-SI13 
flour, ingredients and processing conditions (Doctoral dissertation, School of Applied Sciences, Science, Engineering and Health Portfolio RMIT University, Malaysia).

Danbaba, N., Anounye, J. C., Gana, A. S., Abo, M. E., Ukwungwu, M. N. \& Maji, A. T. (2012). Physical and pasting properties of 'ofada'rice (Oryza sativa L.) varieties. $\mathrm{Ni}$ gerian Food Journal, 30(1), 18-25.

Delgado, T., Paim, B., Pereira, J., Casal, S. \& Ramalhosa, E. (2018). Optimization of osmotic dehydration of chestnut (castanea sativa mill.) slices using response surface methodology. International Journal of Food Studies, 7, 52-68. doi:10.7455/ijfs/7. 1.2018.a5

Dhull, S. B. \& Sandhu, K. S. (2018). Wheatfenugreek composite flour noodles: Effect on functional, pasting, cooking and sensory properties. Current Research in Nutrition and Food Science, 6(1), 174-182. doi:10 . 12944/CRNFSJ.6.1.20

Fagbemi, T. N., Oshodi, A. A. \& Ipinmoroti, K. O. (2005). Processing effects on some antinutritional factors and in vitro multienzyme protein digestibility (ivpd) of three tropical seeds: Breadnut (artocarpus altilis), cashewnut (anacardium occidentale) and fluted pumpkin (telfairia occidentalis). Pakistan Journal of Nutrition, 4(4), 250-256.

FAO/WHO. (2013). Proposed draft maximum levels for hydrocyanic acid in cassava and cassava products. Joint FAO/WHO food standards programme Codex committee on contaminants in foods. CX/CF.13/7/10. Codex Alimentarius Commission E, Rome, Italy.

Harvey, W. \& Morgenstern, M. (2001). Baking Industry Research Trust (BIRT). Flour properties for pasta manufacture. Crop and Food Research confidential report no. 419. Retrieved from https:// bakeinfo.co.nz / files/file/118/issue14.pdf

Hugo, L. F., Rooney, L. W. \& Taylor, J. R. N. (2000). Malted sorghum as a functional ingredient in composite bread. Cereal Chemistry, 77(4), 428-432. doi:10.1094/ CCHEM.2000.77.4.428
Idowu, A. O. (2015). Nutrient composition and sensory properties of kokoro (a nigerian snack) made from maize and african yam bean flour blends. International Food Research Journal, 22(2), 739-744.

Iwe, M., Onyeukwu, U., Agiriga, A. \& Yildiz, F. (2016). Proximate, functional and pasting properties of faro 44 rice, african yam bean and brown cowpea seeds composite flour. Cogent Food \& Agriculture, 2, 1142409. doi:10.1080/23311932.2016.1142409

Koua, G. Y. A., Megnanou, R., Kouassi, A., Séverin Kra, K., N'zue, B., Bi, D. \& Niamké, S. L. (2012). Biochemical characterization of new varieties of yellow colored pulp cassava flours from côte d'ivoire. Journal of Applied Biosciences, 53, 37603772 .

Maga, J. A. (1982). Phytate - its chemistry, occurrence, food interactions, nutritional significance, and methods of analysis. Journal of Agricultural and Food Chemistry, 30(1), 1-9. doi:10.1021/jf00109a001

Mamat, H., Matanjun, P., Ibrahim, S., Amin, S. F. M., Hamid, M. A. \& Rameli, A. S. (2014). The effect of seaweed composite flour on the textural properties of dough and bread. Journal of Applied Phycology, 26 (2), 1057-1062. doi:10.1007/s10811-0130082-8

Maninder, K., Sandhu, K. \& Singh, N. (2007). Comparative study of the functional, thermal and pasting properties of flours from different field pea (pisum sativum 1.) and pigeon pea (cajanus cajan 1.) cultivars. Food Chemistry, 104, 259-267. doi:10. 1016/j.foodchem.2006.11.037

Ndidi, U., Unekwuojo Ndidi, C., Abbas, O., Muhammad, A., Graham Billy, F. \& Oche, O. (2014). Research article proximate, antinutrients and mineral composition of raw and processed (boiled and roasted) sphenostylis stenocarpa seeds from southern kaduna, northwest nigeria. ISRN nutrition, 2014. doi:10.1155/2014/280837

Noor Aziah, A. \& Komathi, C. A. (2009). Acceptability attributes of crackers made from different types of composite flour. International Food Research Journal, 16, 479-482. 
Nutritional Quality of Cassava-African Yam Bean Flour Blends |SI13

Nwokeke, B., Adedokun, I. \& Osuji, C. (2013). Effect of blending on the proximate, pasting and sensory attributes of cassavaafrican yam bean fufu flour. International Journal of Scientific and Research Publications, 3(8), 2250-3153.

Nwosu, J. N., Ahaotu, I., Ayozie, C., Udeozor, L. O. \& Ahaotu, N. N. (2011). The proximate and functional properties of african yam bean (sphenostylis sternocarpa) seeds as affected by processing. Nigerian Food Journal, 29(2).

Ohimain, E. I. (2014). The prospects and challenges of composite flour for bread production in Nigeria. Global Journal of HumanSocial Science, 14(3), 1-11.

Omeire, G. C., Kabuo, N. O., Nwosu, J. N., Peter-Ikechukwu, A. \& Nwosu, M. O. (2015). Enrichment of wheat/cassava noodles with partially deffated proteinrich flour. Journal of Environmental Science, Toxicology and Food Technology (IOSR-JESTFT), 9(5), 121-125.

Omodamiro, R. M., Oti, E., Egesi, C. N., Ukpabi, U. J., Etudaiye, H. A. \& Chijioke, U. (2011). Sensory evaluation of fufu produced from high beta-carotenoid cassava. In 35th annual conference and agm of nigeria institute of food science and technology, markudi.

Omodamiro, R. M., Oti, E., Etudaiye, H. A., Egesi, C., Olasanmi, B. \& Ukpabi, U. J. (2012). Production of fufu from yellow cassava roots using the odourless flour technique and the traditional method: Evaluation of carotenoids retention in the fufu. Adv. Appl. Sci. Res, 3(5), 2566-2572.

Onwuka, G. I. (2005). Food analysis and instrumentation: Theory and practice. Napthali prints.

Oyeku, O. M., Kupoluyi, C. F., Osibanjo, H. A., Orji, C. U., Ajuebor, F. N., Ajiboshin, I. O. \& Asiru, W. B. (2008). An economic assessment of commercial production of $10 \%$ cassava-wheat composite flour bread. Journal of Industrial Research 83 Technology, 2, 20-30.

Qayyum, M. M. N., Butt, M. S., Anjum, F. M. \& Nawaz, H. (2012). Composition analysis of some selected legumes for protein isol- ates recovery. Journal of Animal and Plant Sciences, 22(4), 1156-1162.

Sanni, L., Maziya-Dixon, B., Akanya, J., I. Okoro, C., Alaya, Y., V. Egwuonwu, C., ... Dixon, A. (2005). Standards for cassava products and guidelines for export.

Seibel, W. (2006). Future of flour: A compendium of flour improvement. In L. Popper (Ed.), (Chap. Composite flours, pp. 193198). Bergen: Verlag AgriMedia.

Tanumihardjo, S. A., Bouis, H., Hotz, C., Meenakshi, J. V. \& McClafferty, B. (2008). Biofortification of staple crops: An emerging strategy to combat hidden hunger. Comprehensive Reviews in Food Science and Food Safety, 7(4), 329-334.

Thakkar, S., Huo, T., Maziya-Dixon, B. \& Failla, M. (2009). Impact of style of processing on retention and bioaccessibility of beta-carotene in cassava (manihot esculanta, crantz). Journal of Agricultural and Food Chemistry, 57, 1344-8. doi:10.1021/ jf803053d

UNICEF. (2004). Vitamin and mineral deficiency: A global progress report.

Vasagam, K. P. K. \& Rajkumar, M. (2011). Beneficial influences of germination and subsequent autoclaving of grain legumes on proximate composition, antinutritional factors and apparent digestibility in black tiger shrimp, penaeus monodon fabricius. Aquaculture Nutrition, 17(2), E188-E195. doi:10.1111/j.1365-2095.2009.00748.x

Vimala, B., Thushara, R., Nambisan, B. \& Sreekumar, J. (2011). Effect of processing on the retention of carotenoids in yellowfleshed cassava (manihot esculenta crantz) roots. International Journal of Food Science and Technology, 46(1), 166-169. doi:10.1111/j.1365-2621.2010.02478.x

World Bank. (2009). Nutrition at a glance. world development indicators database. Retrieved from http:// siteresources . worldbank.org / NUTRITION / Resources / 281846-\%201271963823772/nigeria.pdf

IJFS $\mid$ February 2021 $\mid$ Volume 10 $\mid$ pages SI1-SI13 